\title{
Effects of the Online Interactive Learning Media on Student's Achievement and Interest in Physics
}

\author{
Riski Astuti Liliana*, Widodo Raharjo, Ishafit Jauhari, Dwi Sulisworo \\ Ahmad Dahlan University, Indonesia
}

Received August 10, 2019; Revised February 1, 2020; Accepted February 20, 2020

Copyright $\bigcirc 2020$ by authors, all rights reserved. Authors agree that this article remains permanently open access under the terms of the Creative Commons Attribution License 4.0 International License

\begin{abstract}
The use of interactive media integrating digital media and a structured digital environment make student interact with each other for learning purpose. This research developed interactive learning media for enhancing the learning interest and learning achievement of eleventh-grade students. The software used for developing media was Lectora Inspire. This research used the mix method approach. The development model was DDD-E. Subject experts, media experts, and teachers validated the product using a questionnaire containing relevant factors. This instrument used a likert scale from 1 (Absolutely Disagree) to 5 (Absolutely Agree). The teacher applied the valid learning media in the three classes consisting of 108 students to find out the impact on learning interest and learning achievement. Measurement of learning outcomes using multiple choice questions in the cognitive domain. Analysis of learning interest used a questionnaire with a likert scale and used to analyze was MANOVA. As a limitation in this research that interactive media is only accessible for students who have a personal password. Impacts measured have not been on various learning performance indicators, the sequence and variety of types of media. The value of this research is the integration of various kinds of media becomes an opportunity for the media.
\end{abstract}

Keywords Manova, Lectora Inspire, Interactive Learning Media, Learning Achievement, Learning Interest

\section{Introduction}

Education that plays a critical role in the nation and state's life is expected to be the primary support in developing the quality of human resources. The condition refers to the capability to master various branches of skills and expertise that meet the development of sciences and technology including when students study physics. The mastery of the concept of physics and its application become very important in learning at school, where there is no realization of the idea in daily life. With current technology development, both teachers and students can relatively access learning resources in various forms everywhere. Dependency on printed books that are all this time used in the learning process. Electronic books or digital learning materials that are more interactive have replaced them. With more varied learning resources, learning activities become more fun with various learning strategies that are relevant to the teaching materials and student's characteristics. The web-based learning supported by learning material, communication interaction, evaluation activities, and the other resources [1][2] will encourage student learning [3].

A problem in physics learning in various countries is the assumption that physics is not an exciting subject, hard to understand and boring. Some factors that lead to the assumption are the increasing of student's motivation and interest, and the use of learning media that is not suitable. Some factors that cause student's interest in learning science (physics, chemistry, biology) become low are teaching strategies used by the teacher that do not relate the materials to the phenomena in the surroundings, teacher-centered learning that put the teacher as the primary knowledge resource, reflection during the learning process that still less optimal [4]. In this millennial era, the use of technology devices during the learning process has become a trend and familiar for both teacher and students. Information technology literacy of the teacher and students is relatively fair. The development of computers and smartphones can encourage students to learn independently. Nowadays, there are a lot of specific physics learning applications in the market. The applications generally consist of subject summary, learning video, question examples, and evaluation sheet. The learner can use these learning applications on computers and smartphones. Attractive applications are expected to encourage a student's passion for learning physics. Therefore, the 
teacher's capabilities in developing media by using plug and play software become very important. Thus, interactive digital learning media can be produced to support more active and dynamic learning.

One of the characteristics of effective interactive learning media is if students can independently study by using the media to achieve the expected competencies through various activities on the media. A developer can create those interactive media using Lectora Inspire. The software is used to create media that functions as a content management system on physics subject. On this software, a developer can manage contents such as videos, texts, audios, simulations, quizzes, and questionnaires. The simplicity of the software makes interactive learning media development can be easily carried out by teachers.

The development of digital technology gives positive impacts in supporting learning and student's and teacher's performance both inside and outside the classroom. The use of digital technology in education can be carried out flexibly which means that digital technology can be used at all spaces and not only at the classroom [5]. Technology in learning can be used as learning media because learning media are not just books. For the impacts of the technology development that gets more sophisticated, digital media applied in learning is expected to ease the learning process to achieve the learning objectives to improve student's learning achievement and motivation [6]. The technology of computer and internet enables various age groups including teenagers to access learning contents they need very easily [7].

The fact in the real field, most students, still assume that physics is not impressive, hard to understand and boring. Some factors that lead to the assumption are the low student's motivation and interest, and the use of learning media that is not suitable. Therefore, this research would develop interactive media with interactive media supporting software such as Lectora Inspire in physics instruction to engage students during physics learning in class. It aims to find out the effectiveness of the use of interactive media to improve the student's learning achievement and interest.

Research conducted by [8] on the use of visual media applied at classroom showed a fair result. Student's learning achievement and the concept understood could reach $74.51 \%$. The purpose of visual media could increase the average student's learning achievement.

A previous study conducted by [9] on the utilization of Lectora Inspire as interactive learning media concluded that the program was sufficient to be used in learning activities for it was relatively easy to be applied and did not need a sophisticated programming language. Using Lectora Inspire, learning materials were designed attractively by displaying videos, animated images related to learning materials. The research has not shown how much the percentage for the student's learning interest and achievement. Interactive learning media used have not focused on the subject matter taught. The development of interactive multimedia based on Lectora Inspire in chemistry subject in junior high school by [10] concluded that interactive multimedia was valid with an average score validity to fourth aspects to all grades is $98.10 \%$. Research by [11] about Algebraic experience materials with Lectora Inspire stated this model gave its charm; because the technology can provide an exciting animation and can be studied space and time indefinitely in addition to the exercise questions that are easy to learn. The model with the media and square paper helps the student to determine the concept of algebra with significant differences on square paper students must first understand the subject matter concept described by the teacher. Media and material validation results showed that model application meet the quality of the validity, effectiveness, and practical aspects and can motivate learning in both categories.

Development of interactive learning media based Lectora Inspire in discrete method course by [12] based on the results, the interactive learning media has been reviewed by the experts and some suggestions from them have been implemented to get a better interactive learning media. The students also gave their perceptions, and they thought that the developed interactive learning media should be used regularly in discrete method class, although some aspects have to be improved. Therefore, it implied that the development of interactive learning media is practical and valid in a discrete method course.

The interactive learning media have significant effects of increasing the student's learning outcomes. It showed by the results of the field test at 23 students of discrete method class in the Department of Mathematics, Sriwijaya University, Indonesia. Based on the test score, the student's average score increased to 72.61 in the post-test from 58.7 in the pre-test.

Examples of techniques to increase learner's interest in the computer-based multimedia presentation include using a human voice rather than a machine voice (voice principle) and using the word in a conversational style rather than a formal form (personalization principle). Overall, design principles based on increasing interest succeed when they encourage learners to use their available cognitive capacity for active cognitive processing during learning that is, to organize the presented materials into coherent representations and integrate the pictorial and verbal descriptions and with prior knowledge [13].

Learning media is an essential element to support the success of learning activities. It is used to deliver a message and stimulate student's thought, feeling, attention and interest that it would help the learning process with deliberate, intended and controlled strategies. Besides, the use of creative media can increase student's interest and talent, learning motivation, and accelerate and increase learning efficiency [14]. It now needs to be considered before the teacher teaches in the classroom. The use of media could immensely influence students. 
Multimedia are instruments that can create dynamic and interactive presentations which combine texts, graphics, animation, audios, and videos. Specifically, multimedia refers to the use of computers to make and videos by using link tools which enable the user to navigate, interact, create and communicate. Interactive multimedia synergize all media consisting of texts, graphics, audios and interactivities [15] [16], the use of multimedia in physics learning is expected to stimulate student's learning passion and interest so it can increase the student's learning achievements.

The learning achievements are one's capabilities after experiencing learning. The learning achievements have essential roles in the learning process. One of them is giving information to the teacher about student's improvement in achieving learning objectives through learning activities. The learning outcomes include three; those are skills and habits (psychomotor), knowledge and understanding (cognitive), and attitudes (affective) and goals that each group can be filled out with materials in the school curriculum [17-20].

Learning interest is an internal factor or factor from self-inside that influences student's learning. It occurs because a strong willingness to increase dignity or get a good job and have a fun and happy life. High learning interest tends to produce high achievement, vice versa [21].

Lectora Inspire is software that can be used by educators as a means of developing learning media. The media produced is learning multimedia. The rapid development of technology has allowed for the integration of multimedia technology into teaching-learning process, and multimedia provides a constructivist learning environment in which students can solve the problem through self-exploration, collaboration, and active participation. Through multimedia, the teacher can enhance the reciprocal relationship between teacher and students [22-24].

Based on the explanation above, researchers studied conducted research on developing the online interactive learning media to improve student's achievement and interest on physics.

Nowadays physics learning is not in demand by students, this happens because the way the teacher in delivering physics material is less fun and the methods or media of learning supporting physics are not updated. So that the use of learning media products that have been developed with the help of this Lectora Inspire software to provide solutions as a practical activity and student examination. The equipment used during practicum is equipment that adapts to technology that is currently actively used by students. Technology is generally used for social media activities. Today's teens prefer to play with gadgets as seen in daily activities. Technology equipment that attracts students so students have a strong interest in practicing the lab. In addition, the use of technological equipment as an attraction for active students to find out about the material of physics that will be studied. Interactive learning media practicum products can be applied to laptop or computer and cellphones. So that students can learn about their interest in applying technology such as computers or laptops and cellphones. Not only practicum that can use interactive media applications but for test or test sheets students can also use the equipment. For the retrieval of student learning outcomes can be used with interactive media assisted by software Lectora Inspire.

The method used this research is research and development with the procedural model. Research and Development is a research method used to produce a particular product and test the effectiveness of the product.

\section{Methods}

\subsection{Research Design}

The development model adopted has four phases which are 3D and 1E. The step of Decide focuses on deciding program objectives and materials. The stage of Design shows the program structure, and the phase Develop covers media production and programming. The stage of Evaluate views the whole process during multimedia development. This research referred to the development model of DDD-E (Decide, Design, Develop, and Evaluate). Visualization of the DDD-E model is shown by Fig. 1 [25].

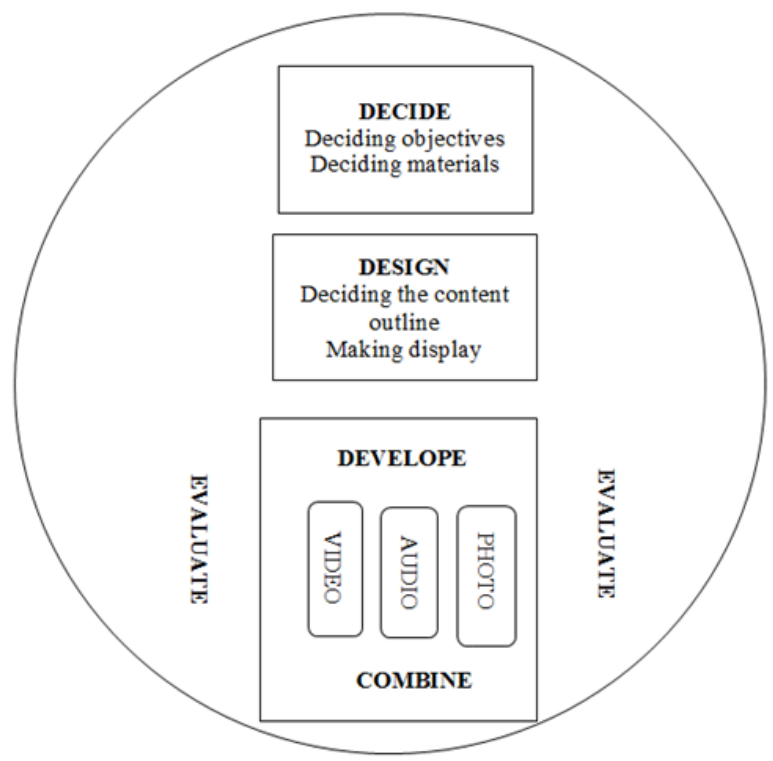

Figure 1. The research development model

The research design used was ex post facto. Non-experiment research or ex post facto is a method commonly used in the situation faced by a lot of educational studies.

\subsection{Research Subject}

The subject of this research was eleventh-grade students 
of a senior high school in Samarinda, Indonesia consisting of 3 classes, in the academic year of 2018/2019. Each class consisted of 36 students, so the total was 108 students.

\subsection{Instruments}

The research instruments cover all tools used during the validation process to find out the validity of the presented media and materials. Data of score was changed into qualitative data (interval data) by using the Likert scale to find out the quality of the interactive learning media from the development result, d. For the Likert scale, the highest score is 5 (Absolutely Agree), and the lowest is 1 (Absolutely Disagree). The next is evaluating the feasibility of the interactive learning media implemented in physics subject of the eleventh grade of senior high school in Samarinda, Indonesia.

The research instruments used during the learning process were student worksheets as enclosed. These instruments were used to ensure the direction of student's activities. The tools for data collection consisted of (1) questionnaires to find out student's learning interest towards the learning media implemented, and (2) cognitive test with multiple choice question items used to find out student's learning achievement after the implementation of the interactive learning media.

\subsection{Analysis Technique}

Validity is a measurement that shows the validity level of an instrument. An instrument is valid if it measures and reveals data of variables accurately and precisely. High and low validity of an instrument shows how far collected data does not diverge from the description about variables referred.

Knowing the Alpha Cronbach equation, the criteria of reliability coefficient (r) is as the following Table 1 . The whole data obtained from student's learning achievement and interest will be analyzed by Manova technique to find out whether the acquired data from three classes are different or not.

Table 1. Classification of Reliability Coefficient

\begin{tabular}{|c|c|}
\hline $\mathrm{r}$ & Criteria \\
\hline $0.00-0.20$ & Very Low \\
\hline $0.20-0.40$ & Low \\
\hline $0.40-0.60$ & Fair \\
\hline $0.60-0.80$ & High \\
\hline $0.80-1.00$ & Very High \\
\hline
\end{tabular}

\section{Result and Discussion}

\subsection{Result}

This research is Research and Development that aims to produce interactive learning media by using Lectora Inspire software. By applying the design phases of learning media production, a physics media on the physics discussion topic was created. This interactive learning media was utilized towards eleventh-grade students at senior high school in Samarinda to help students in studying physics. The phases in this research have four stages which were Decide, Design, Develop, and Evaluation.

\subsubsection{Decide}

In this phase, observation towards senior high schools in Samarinda, Indonesia was done to decide the research location. It aimed to find out the materials to discuss and the objectives of the research. This school needed the newest strategies and teaching materials for physics subject matter. The condition of the school is good enough, and the facilities at school could support the learning activities. The facilities were such as science laboratory, computer and language laboratory, and LCD projector. Some teachers had taught by using digital devices and some others still used conventional method for example teachers of physics subject. Based on the observation result towards physics teachers, it seemed that teachers frequently used lecture method and seldom used digital facilities. Whereas, education now days requires teachers to be able to activate learning combined with the use of digital technology.

At school, generally, every student has a laptop, smartphone, and internet network. However, teachers had not maximized the use of the devices well because of the limited knowledge related to the technology. The curriculum used was Curriculum 2013 where this curriculum requires students to be able to independently search for information about teaching materials and teachers act as facilitators and mediators. In this curriculum, students are the center of the learning activities in class. Therefore, by using this Curriculum 2013, researchers had initiatives to develop online-based products of teaching materials which were new for teaching materials at that school.

\subsubsection{Design}

In this part, learning media was designed based on the materials in forms of images, videos and combined with a virtual lab, so during the learning process; students could carry out practicum through digital media related to competencies and learning objectives to achieve. The next activity was designing the display of learning media containing videos or images combined with physics material explanation.

\subsubsection{Develop}

The process of developing media was carried out by combining audios or images that matched the subject matter. The next was editing in the process of developing interactive media. The result of editing phase was next 
published online with Lectora Inspire then uploaded on website. The web address of this media is http://www.fisikaonline.rizkiastutililiana.com. Lectora Inspire gives facilities in creating interactive media and could be combined with several contents such as videos, graphics, audios, and animation. The learning of media creation is expected to make students more enthusiastic in studying physics. Fig. 3 to Fig. 4 represent the product of the media.

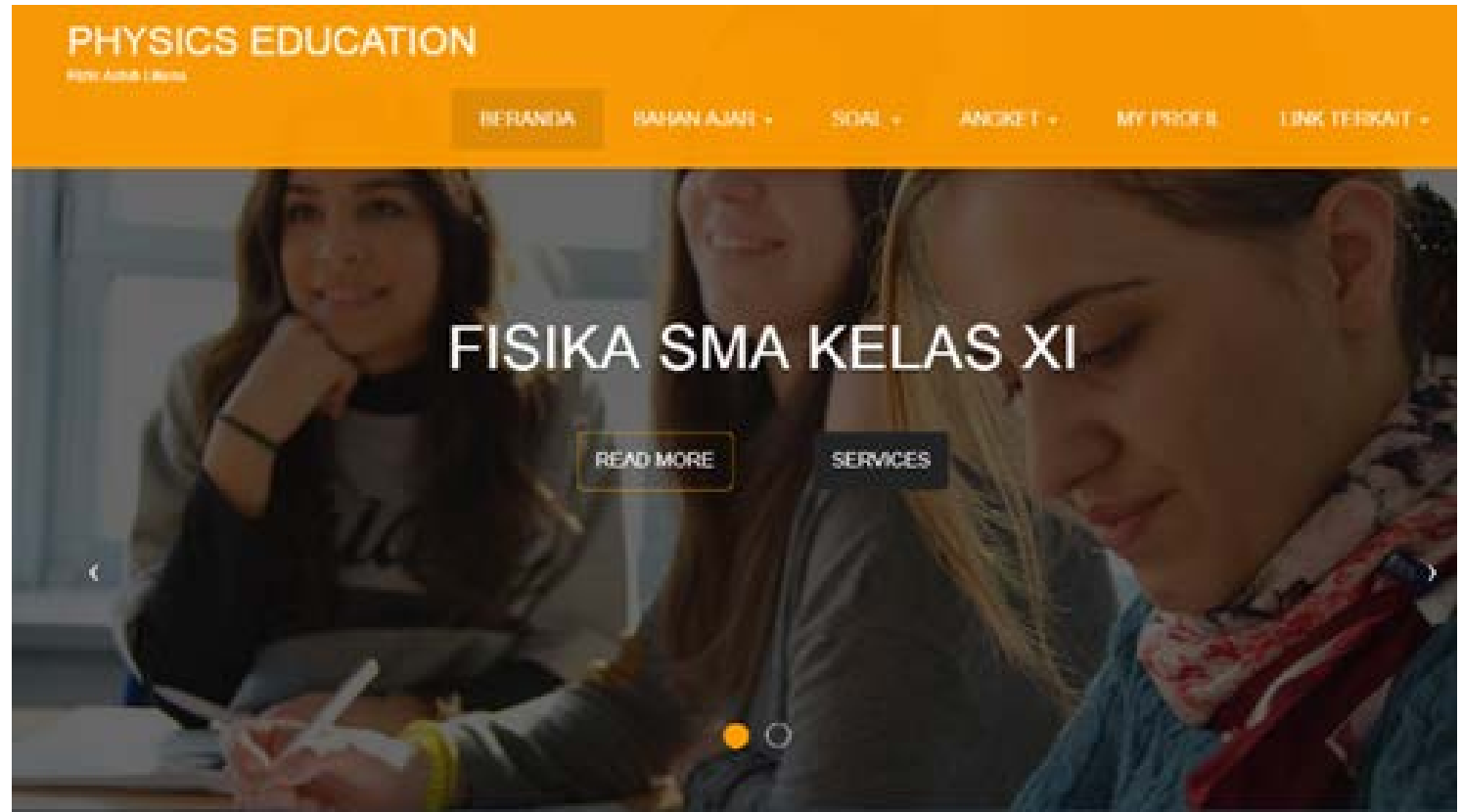

Figure 2. The home screen. There are some features: home (BERANDA), learning material (BAHAN AJAR), evaluation (SOAL), questionnaire (ANGKET), creator profile (PROFIL), and ling to other important things (LINK)
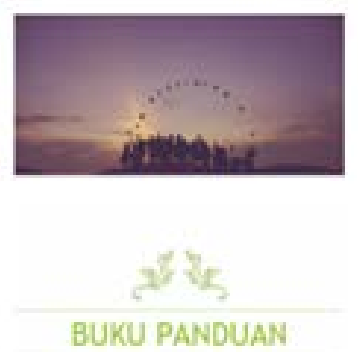

BUKU PANDUAN

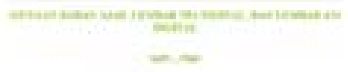

Fisika SMA Kelas XI

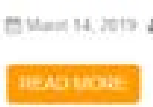

\section{Panduan Media}

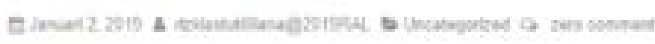

\section{Benoware}

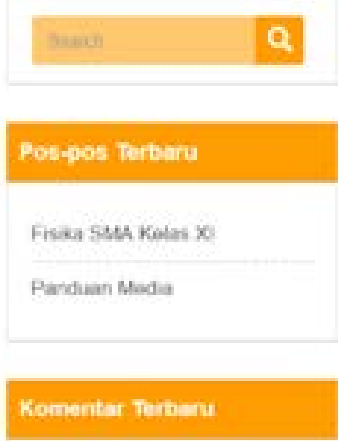

Arsip

Figure 3. Other features in the home screen: manual (Panduan Media), new posting activities (Pos-pos Terbaru), comment input (Komentar Terbaru), archives (Arsip) 


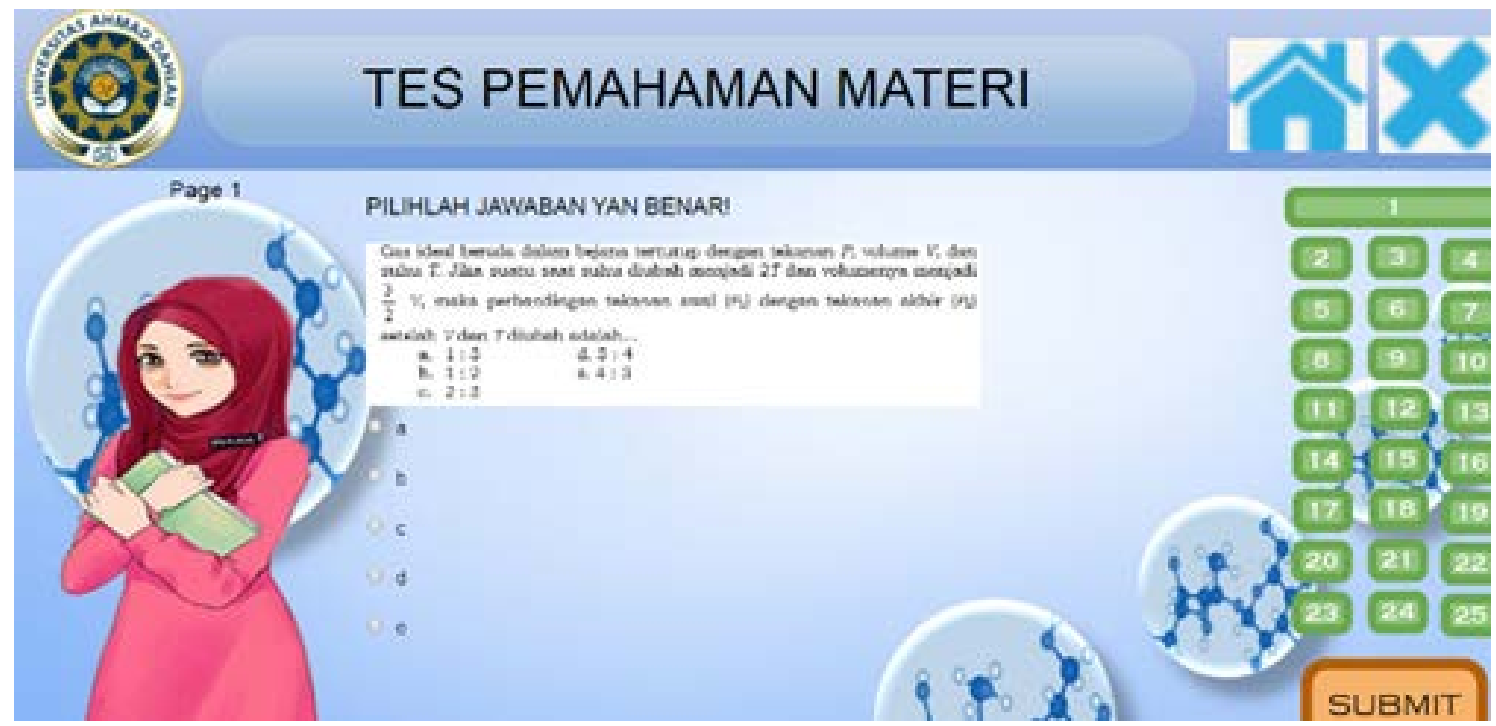

Figure 4. Screenshot of the evaluation sheet. It is a link (https://soal.rizkiastutililiana.com/) consisting of 25 multiple choices formative test. The student may proceed after finishing all the question. This sheet measures the student understanding related to the learning subject

\subsubsection{Evaluate}

This phase was the phase of the validation process of media and research instruments used in the research. Validation process was carried out by involving expert validators such as a media expert, a material expert and an expert in questionnaires of interest and response. In addition to expert validators, the teacher also validated the media on the related subject matter. Data collection used questionnaires, a test sheet, and documentation.

This research aims to develop interactive media or learning application by using Lectora Inspire since teachers are required to be able to operate specific technology in the educational field. The development of technology now supports human beings to live practically and efficiently. The product presented was teaching material media for the subject matter of the gas kinetic theory. The media expert and subject matter expert validated the learning media. Questions and questionnaires used during the research were evaluated in material aspects of language, software utilization, visual communication display, media display, and substance. Subject matter expert estimated issues such as language, questions based on Bloom taxonomy, questions based on school curriculum, presentation, and content. Interest expert aspects being assessed such as fun feeling, participation or involvement, and attention of students. Fig. 5 shows the result of the ME validation.

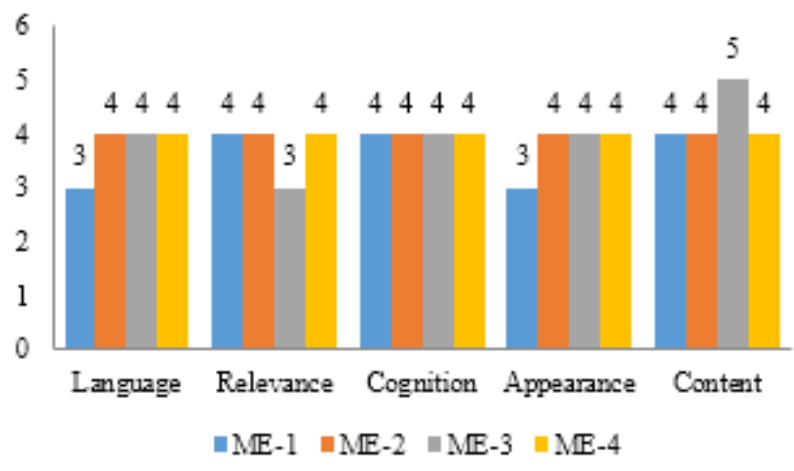

Figure 5. The Result of Material Validation Score

Each material expert (ME) provides an assessment and assessment from experts (distinguished by different color in the figure). From Fig. 5, the validation for the material used consisting of five aspects comprising of language which used standard and simple one (Language), comply to the competency based on the school curriculum (Relevance), items of the cognition domain level according to Bloom's taxonomy (Cognition), presentation and content (Content). Of these five aspects, almost experts score above four on a scale of 5 . Overall, the average score for material validation from experts is 3.9. This figure shows that the media developed is good from material or learning subject validation. 


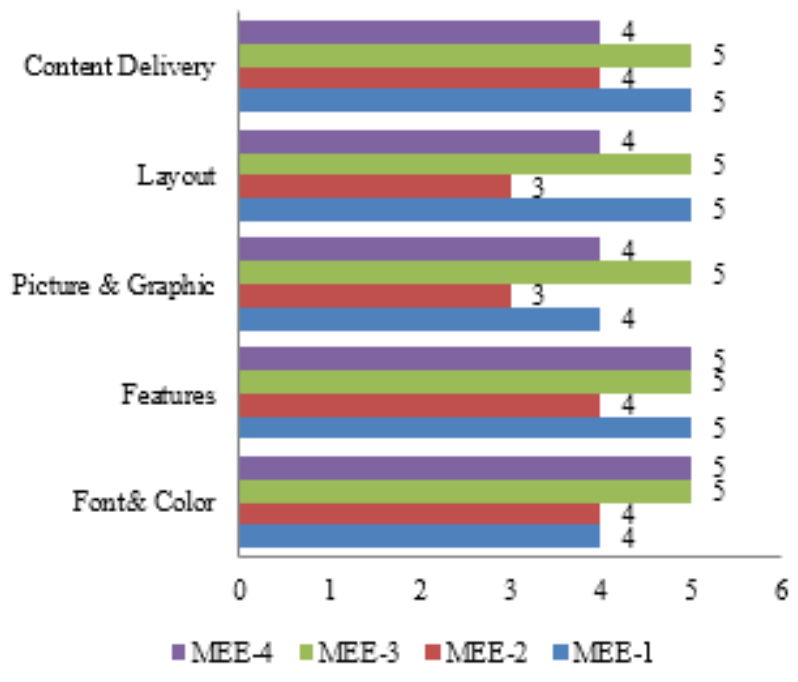

Figure 6. The Result of Media Validation

Fig. 6 shows the results of interactive media validation that has been developed for media experts (MEE) consisting of four experts each expert assesses learning products based on five aspects such as font and color selection (font \& color), application software utilization (feature), visual or display communication (visual), position and portion of each part appearance (layout) and substance sequence delivery (content delivery). From Fig. 6 , all experts score above 3 for all aspects. The average media validation score is 4.4 of scale 5 . Thus, media appearance validation is as good criteria.

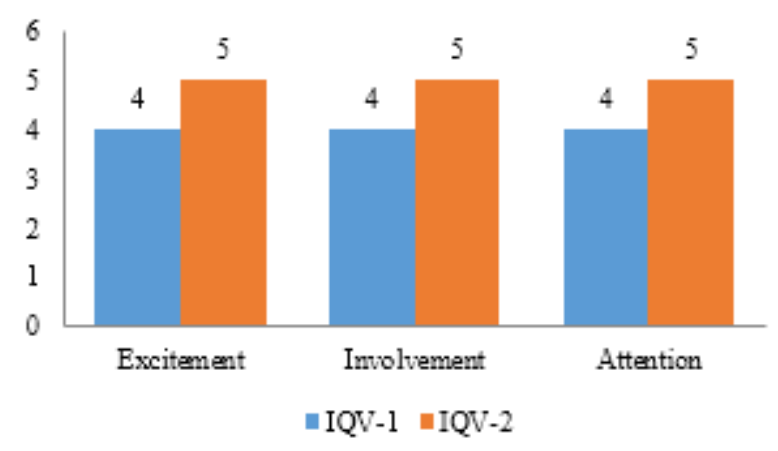

Figure 7. The Result of Interest Validation Score

There are two variables to measure the impact of media developed on students who use it in learning namely learning achievement and learning interest. Learning achievement measurement is to adjust to the learning objectives in the school setting emphasizing the achievement of the cognitive domain, especially in the understanding of subject matter. In this study, learning achievement was measured using a multiple choice test which amounted to 25 items. This test is provided in the form of a link connected to the primary web. Questions type are from easy to challenging levels. All questions are following the needs of the national exam in the field of physics at the high school level.

Learning interest measurement is collected to explain the intervening impact on what happened - theoretically, the increasing of learning interest influence the increasing of learning achievement. So, finding out the importance of students in the interactive media is very much needed a measuring instrument to find out this one. For the measurement request, the researcher developed a student interest questionnaire (IQV). Two relevant experts (IQV-1 and IQV-2) validated the measuring instrument. Validator provides an assessment based on three aspects of evaluation, namely feeling happy (excitement), participation or involvement of students (involvement) and student attention (attention). From Fig. 7, the two experts considered that the interest questionnaire was in criteria both with an average score of 4.5 on a scale of 5 .

\subsubsection{Manova}

The teacher uses media developed in classroom learning. There are three classes (CL) which are taught using this media with a total of 108 students. The learning achievement data (VAR-1) and learning interest (VAR-2) are then utilized using MANOVA statistical techniques with alpha 0.05 . The results of data processing are shown in Table 2 for descriptive statistics and Table 3 for multivariate testing.

Table 2. Descriptive Statistic

\begin{tabular}{|c|c|c|c|c|}
\hline & Class & Mean & Std. Deviation & $\mathbf{N}$ \\
\hline \multirow{4}{*}{ VAR-1 } & CL-1 & 77.92 & 5.664 & 36 \\
\cline { 2 - 5 } & CL-2 & 74.03 & 3.783 & 36 \\
\cline { 2 - 5 } & CL-3 & 76.08 & 4.462 & 36 \\
\cline { 2 - 5 } & Total & 76.01 & 4.923 & 108 \\
& CL-1 & 69.86 & 5.967 & 36 \\
\cline { 2 - 5 } VAR-2 & CL-2 & 77.92 & 5.664 & 36 \\
& CL-3 & 66.86 & 6.193 & 36 \\
\cline { 2 - 5 } & Total & 71.55 & 7.529 & 108 \\
\hline
\end{tabular}

Table 2 shows the mean of achievement and interest in each class. For the VAR-1, the mean value of CL-1 is 77.92, CL-2 is 74.03, and CL-3 is 76.08. For VAR-2, the mean value of VAR-2 of CL-1 is 69.86, CL-2 is 77.92, and CL-3 is 66.86. Based on output Box's test of the quality of covariance metrics, the significant value of covariance result is 0.000 . Because a significant amount is less than 0.05 so, we can analyze using MANOVA technique as multivariate tests. See Table 3 for the result. 
Table 3. Multivariate Tests

\begin{tabular}{|c|c|c|c|c|c|c|}
\hline \multicolumn{2}{|c|}{ Effect } & Value & F & df & Error & Sig. \\
\hline \multirow{3}{*}{ Intercept } & Pillai's Trace & .998 & $2.122 \mathrm{E} 4^{\mathrm{a}}$ & 2 & 104.0 & .000 \\
\cline { 2 - 7 } & Wilks' Lambda & .002 & $2.122 \mathrm{E} 4^{\mathrm{a}}$ & 2 & 104.0 & .000 \\
\cline { 2 - 7 } & Hotelling's Trace & 408.137 & $2.122 \mathrm{E} 4^{\mathrm{a}}$ & 2 & 104.0 & .000 \\
\cline { 2 - 7 } & Roy's Largest Root & 408.137 & $2.122 \mathrm{E} 4^{\mathrm{a}}$ & 2 & 104.0 & .000 \\
\hline \multirow{3}{*}{ Class } & Pillai's Trace & .463 & 15.816 & 4 & 210.0 & .000 \\
& Wilks' Lambda & .556 & $17.707^{\mathrm{a}}$ & 4 & 208.0 & .000 \\
\cline { 2 - 7 } & Hotelling's Trace & .762 & 19.619 & 4 & 206.0 & .000 \\
& Roy's Largest Root & .713 & $37.416^{\mathrm{b}}$ & 2 & 105.0 & .000 \\
\hline
\end{tabular}

Based on the output of multivariate test on Table 3, the significant value is seen on Pillai's trace, Wilk's lambda, Hotelling's trace, and Roy's largest root on effect classes and the overall result are 0.000 . Because of the significant value is less than 0.05 , then according to decision criteria, there is a difference between student's learning achievement (VAR-1) and interest (VAR-2) of three classes in terms of the increase.

\subsection{Discussion}

Effectiveness test towards interactive learning media of physics subject matter was carried out on the phase of Evaluate. This phase used three sample groups consisting of 36 students each. The subjects used for effectiveness test were students of eleventh-grade students 1,2 and 3 . There were two things observed from the result of effective analysis which was the increase of student's learning achievement and interest.

\subsubsection{Learning Achievement}

The learning achievement observed was only cognitive aspect on the level of understanding. The completeness of learning achievement is viewed from $70 \%$ of students who passed the minimum completeness criteria. Before using the application, the percentage of student's learning achievement was different because of the gain score from each class. The difference in student's learning achievement (VAR-1) before and after using the application or gain score of (CL-1) was 0.48 that shows good criteria. The gain score of (CL-2) was 0.27 that shows the learning achievement difference in low criteria. The gain score of (CL-3) was 0.43 that shows good criteria. Each gain score of (CL-1), (CL-2), and (CL-3) indicates that the difference in student's learning achievement (VAR-1) score before and after using the Lectora Inspire based application has a significant change.

This finding can be seen from the increase in student's learning achievement. Before the implementation, the average of learning achievement of (CL-1), (CL-2), and
(CL-3) were 68, 66, and 65 respectively. After using the media on physics instruction, the percentages increased. The portion of the learning achievement of (CL-1) was 88, (CL-2) was 75, and (CL-3) was 86. The proportions of each class are different because of different capacity, comprehension, and level of understanding of each student. Students will be enthusiastic about learning if learning is interesting supported by the interactive learning media. Besides, this media is also embedded with the figure, animation, and questions that can be answered directly.

\subsubsection{Learning Interest}

The rise of student's learning interest in each experimental class is viewed from the score before and after the implementation of learning by using interactive media. Before using the application, the percentage of student's learning achievement was different because of the gain score from each class. The difference between student's learning interest before and after using the application or gain score of (CL-1) was 0.41 that shows good criteria. The gain score of (CL-2) was 0.34 that shows the learning achievement difference in low criteria. The gain score of (CL-3) was 0.28 that shows low criteria. Each gain score of those three classes indicates that the difference in student's learning achievement score before and after using the application has a significant change.

After the implementation of the application on physics instruction particularly on the subject matter of physics, the average score of VAR-2 in (CL-1) was 88, in (CL-2) was 75 , and in (CL-3) was 86. The portions of each class are different because of different capacity, comprehension, and level of understanding of each student. The level of the part of student's learning interest every classroom is different because of the difference in student's fun feeling situation. However, the use of interactive learning media is proven able to increase a student's learning interest [26].

\subsubsection{Manova}

Based on the output of multivariate test on table 3 above, significant value seen on Pillai's trace, Wilk's lambda, 
Hotelling's trace, and Roy's largest root on effect classes and the overall result is similar which is 0.000 . The significant value is less than 0.05 , so according to decision-making criteria, there is a difference between student's learning achievement and interest of three classes in terms of the increase.

\section{Conclusions}

This learning media has a good interactive level. The results are shown in the validation of learning material experts and media experts. The use of this media in learning is proven to improve learning performance. Interactive media is feasible to enhance learning based on the analysis result of questionnaires. Based on the outcome of the research, it appears that student's learning achievement and interest significantly increase. It can be seen on the presented graph, so it can be concluded that interactive media developed is effective to improve the student's learning achievement and interest on physics learning.

\section{Acknowledgements}

This research is funded by the Ministry of Research, Technology and Higher Education of the Republic of Indonesia through Graduate Student Research Grant Year 2019.

\section{REFERENCES}

[1] Gulnara B, Ilyas Z, \& Gulnara Z. The development of a web application for the automatic analysis of the tonality of texts based on machine learning methods. In International Conference on Control, Automation and Systems, 101-103, 2018.

[2] Khwaja AA (2018). A web-based program outcome assessment tool. In the 21st Saudi Computer Society National Computer Conference, NCC 2018.

[3] Zakir S, \& Hidayat R. Web-based learning model that can be implemented in learning settings without being limited by time, place and space. Journal of Theoretical and Applied Information Technology, Vol. 96, No. 23, 7996-8005, 2018.

[4] Nasution R, Silaban S, \& Sudrajat A. The Influence of Problem Based Learning, Guided Inquiry Learning Models Assisted by Lectora Inspire, and Scientific Attitudes to Student's Cognitive Values. In 3rd Annual International Seminar on Transformative Education and Educational Leadership (AISTEEL 2018). Atlantis Press, 2018.

[5] Martin F, \& Ertzberger J. Here and Now Mobile Learning: An Experimental Study on The Use of Mobile Technology. Computer and Education, Vol. 68, 76-85, 2013.
[6] Fajrina W, \& Simorangkir M. Developing Interactive Computer Based Learning Media of Lectora Inspire to Enhance Conceptual Skills of Senior High Schools Students. In 3rd Annual International Seminar on Transformative Education and Educational Leadership (AISTEEL 2018). Atlantis Press, 2018.

[7] Liu CC, \& Jou M. An Interactive Web-based Learning System for Assisting Machining Technology Education. International Journal of Online and Biomedical Engineering (iJOE), Vol. 4, No. 2, 43-47, 2008.

[8] Soebroto T, Priatmoko S, \& Siyamita N. The influence of visual media in the classroom on students' interest and chemistry learning outcomes. Educational Innovation Journal, Vol. 3, 400-402, 2009.

[9] Shalikhah ND. Utilization of the Lectora Inspire Application as an Interactive Learning Media Journal Cakrawala, Vol. 9, 103-105, 2016.

[10] Herdini. Development of Interactive Multimedia Based on Lectora Inspire in Chemistry Subject in Junior High School or Madrasah Tsanawiyah. Journal of Education Science, Vol. 2, No. 1, 47-50, 2018.

[11] Sugilar H, Nuraida I, Irwansyah FS, \& Ramdhani MA. Algebraic Experience Material with Lectora Inspire. IOP Conf. Series: Materials Science and Engineering, Vol. 434, $1-2,2018$.

[12] Faruk A. Development of Interactive Learning Media Based Lectora Inspire in Discrete Method Course. In International Conference on Research, Implementation, and Education of Mathematics and Sciences, 69-70, 2014.

[13] Mayer RE, Fennell S, Farmer L, \& Campbell J. A Personalization Effect in Multimedia Learning: Students Learn Better When Word Are in Conversational Style Rather than Formal Style. Journal of Educational Psychology. Vol. 96, No. 2, 389-395, 2004.

[14] Nurbaiti, P, \& Titin. The Properness of Adobe Flash Basis Interactive Media for Respirator System Learning Material. UNNES Sciences Education Journal, Vol. 6, No. 3, 1663, 2017.

[15] Arjawa AA. Developing Instructional Multimedia for Teaching Line and Angle to The seven-grade Students of Junior High School. International Journal of Engineering and Computer Science, Vol. 1, No. 1, 6-13, 2018.

[16] Oktavianingtyas E, Salama FS, Fatahillah A, Monalisa LA, \& Setiawan TB. Development 3D Animated Story as Interactive Learning Media with Lectora Inspire and Plotagon on Direct and Inverse Proportion Subject. Journal of Physics, Vol. 1108, 1-2, 2018.

[17] Nur MA. Improve Mathematics Learning Outcomes through the Application of Think-Pair Cooperative Learning for $7^{\text {th }}$ Grade Students B State Junior High School 10 Ujung Loe Kabupaten Bulukumba. Mathematics and Natural Science Education Journals, Vol. 2, 143-145, 2017.

[18] Rahayu AB, Hadi S, Istyadji M, Zaini M, Sholahuddin A, \& Fahmi. Development of Guided Inquiry-Based Learning Device to Improve Student Learning Outcomes in Science Materials in Middle School. European Journal of Alternative Education Studies, Vol. 3, No. 2, 107-110, 2018. 
[19] Ashmore JL, Knettler-Smith AS, \& Scott SS. Use of Student Learning Outcomes in Postsecondary Disability Offices. Journal of Postsecondary Education and Disability, Vol. 31, No. 2, 110-111, 2018.

[20] Suskevics M, Hahn T, Rodela R, Macura B, \& Pahl-Wostl C. Learning for Social-ecological Change: A Qualitative Review of Outcomes Across Empirical Literature in Natural Resource Management. Journal of Environmental Planning and Management, Vol. 61, No. 7, 1-3, 2018.

[21] Dalyono M. Educational Psychology, Rineka Cipta, Jakarta, 2012.

[22] Akbarini NR, Murtini W, \& Rahmanto AN. Design of Interactive Learning Multimedia Development in General Administration Subject. International Journal of Multicultural and Multireligious, Vol. 5, No. 4, 138-148, 2018.

[23] Sanwidi A, \& Swastika GT. Lectora Inspire in Learning Congruence Triangles on Higher Education. Scientific Journal of Mathematics Education, Vol. 7, No. 1, 67-69, 2018.

[24] Wibawa SC, Harimurti R, Anistyasari Y, \& Sumbawati MS. The Design and Implementation of an Educational Multimedia Interactive Operation System Using Lectora Inspire. Electronics, Information, and Vocational Education, Vol. 2, No. 1, 74-77, 2017.

[25] Saifullah A. Development of Learning Modules Assisted by Instagram Social Networking Sites to Improve Learning Outcomes of Multimedia Design Subjects. Journal UNESA, Vol. 1, No. 2, 70-75, 2016.

[26] Astuti IAD, Sulisworo D, \& Firdaus T. What is the student response to using the weblogs for learning resources? In Journal of Physics: Conference Series, IOP Publishing, Vol. 1157, No. 3, p. 032012, 2019. 